\title{
Effect of Temperature on Two-phase Anaerobic Reactors Treating Slaughterhouse Wastewater
}

\author{
Simone Beux, Ezequiel Nunes and Ana Cláudia Barana* \\ Departamento de Engenharia de Alimentos; Universidade Estadual de Ponta Grossa; Av. Gal. Carlos Cavalcanti, \\ 4748; Campus Uvaranas; 84030-900; acbarana@uepg.br; Ponta Grossa - PR -Brasil
}

\begin{abstract}
The effectiveness of the anaerobic treatment of effluent from a swine and bovine slaughterhouse was assessed in two sets of two-phase anaerobic digesters, operated with or without temperature control. Set A, consisting of an acidogenic reactor with recirculation and an upflow biological filter as the methanogenic phase, was operated at room temperature, while set $B$, consisting of an acidogenic reactor without recirculation and an upflow biological filter as the methanogenic phase, was maintained at $32^{\circ} \mathrm{C}$. The methanogenic reactors showed COD (Chemical Demand of Oxygen) removal above 60\% for HRT (Hydraulic Retention Time) values of 20, 15, 10, 8, 6, 4, and 2 days. When the HRT value in those reactors was changed to 1 day, the COD percentage removal decreased to $50 \%$. The temperature variations did not have harmful effects on the performance of reactors in set $A$.
\end{abstract}

Key words: Effluent, slaughterhouse, treatment, anaerobic, two-phase

\section{INTRODUCTION}

Brazil has one of the largest herds of the main species of animals with commercial value in the world, including bovines, swine, and fowls. The agroindustrial complex that comprises this type of activity is quite wide, involving several sources of the residues in practically all its steps, as a consequence of the rearing and processing of animals (Pohlmann, 2004). Effluent from industrial poultry, porcine or bovine slaughterhouses containing lipids, proteins, blood, and other organic material, might cause environmental damage if discharged untreated in rivers and creeks (Kobya et al., 2005; Chaves et al., 2005).

Slaughterhouses generate a high volume of the residues, and water consumption varies depending on the type of animal and the process used in each industrial plant. The major part is disposed as effluents, with ranges from 1.5 to $2.0 \mathrm{~m}^{3}$ per sacrificed bovine, and 1.0 to $1.5 \mathrm{~m}^{3}$ per sacrificed swine (Pohlmann, 2004). Processing a chicken for the human consumption requires 12 to $24 \mathrm{~L}$ of water (Chaves et al., 2005). According to the Brazilian Union of Aviculture, the production of chicken in 1998 was around $4.5 \times 10^{6}$ ton (Cansian et al., 2005). The variation in quantity and organic load present in the effluents from different industries depends on the degree of recycling and care taken during the operation, particularly with blood (Ruiz et al., 1997; Pohlmann, 2004).

Most organic matter present in the slaughterhouse residues is biodegradable, usually ranging from 1100 to $2400 \mathrm{mg} \mathrm{O}_{2} \mathrm{~L}^{-1}$ in terms of Biochemical Oxygen Demand $\left(\mathrm{BOD}_{5}\right)$, with the soluble fraction varying between 40 and $60 \%$. The insoluble fraction is formed by the colloidal and suspended

\footnotetext{
${ }^{*}$ Author for correspondence
} 
matter, in the form of fats, proteins, and cellulose, which can be slowly decomposed in anaerobic reactors (Johns, 1995; Núñez; Martinez, 1999; Allie et al., 2003). Pretreatments such as screening, catch basins, flotation, equalization, and settlers are used for removing the suspended solids in the wastewater (Mittal, 2005). Blood, meat peaces and other animal byproducts are used in rendering the plants for feedstock production (Mittal, 2005).

Aerobic processes are not regarded as a suitable treatment option because of high energy requirements for the aeration, limitation in liquidphase oxygen transfer rates, and large quantities of sludge production (Torkian et al., 2003).

Anaerobic systems have been studied for the treatment of industrial effluents because they are effective in removing the organic load, with significantly lower costs when compared with the aerobic processes. Due to the growing knowledge about household sewage treatment systems, anaerobic processes are acquiring a prominent position worldwide, especially in the tropical climate countries such as Brazil, where the environmental conditions are favorable for this type of the treatment (Chernicharo, 1997). Fullscale UASB (Up-flow Anaerobic Sludge Blanket) reactors are in operation now in India, Colombia and Brazil (Halalsheh et al., 2005). Anaerobic fixed-bed reactors have been increasingly used to treat the domestic sewage in recent years because of the good performance and stability, whose main contributing factors are long cellular retention time and high biomass concentrations (Lima et al., 2005).

In cases where the effluents show high concentrations of biodegradable organic matter, with BOD values two to four times higher than household sewage, such as slaughterhouse effluents, aerobic treatment processes can be very costly due to the high consumption of energy required for the aeration, for the oxygen transfer capacity, and for the high production of sludge, which requires post-treatment. In such cases, anaerobic digestion may become an interesting alternative (Di Berardino et al., 2000; Del Pozo et al., 2000; Allie et al., 2003).

Slaughterhouse residues can be treated by the means of anaerobic digestion, since they contain high concentrations of the biodegradable organic load, sufficient alkalinity, and suitable concentrations of phosphorus, nitrogen, and micronutrients for the bacterial growth (Massé,
Masse, 2001). These residues generally contain high concentrations of the fat. Single-phase, UASB type anaerobic digesters are considered impractical, because the fat present may form thick foam inside the reactor, compromising the operation (Chen, Shyu, 1998; Del Pozo et al., 2000; Torkian et al., 2003; Barreto, 2004).

Usually, the anaerobic treatment process includes two metabolic phases, the acidogenic phase and the methanogenic phase, although the acidification and methanation usually occur simultaneously in an anaerobic reactor (Wang et al., 2006). Anaerobic digestion in two physically separated phases was first suggested by Pohland and Ghosh (1971). This type of configuration aims to encourage the growth of different microbial populations in the distinct reactors (Yenigün, Yilmazer, 1999). The acidogenic bacteria and methanogenic archaea show different characteristics, especially with respect to their nutritional requirements, physiology, $\mathrm{pH}$ of the growth, and ability to withstand the environmental changes (Anderson et al., 1994). Due to these different growth characteristics between them, operational conditions that could maximize the formation of acids and methane can be obtained in a process with two physically separated phases allowing the selection and enrichment of different groups of the microorganisms, with an independent control of the operational conditions in each reactor. Therefore, the first phase can be operated to prioritize the growth of the acidogenic bacteria, while the second phase can encourage methanogenic archaea growth, increasing the efficiency of the conversion of the organic matter to acids, and acids to methane at each corresponding phase (Anderson et al., 1994; Ince, 1998; Demirer, Chen, 2005). In an evaluation of a two-stage anaerobic digester for the treatment of mixed abattoir wastes, Wang and Banks (2003), observed that the use of a single-pass digester showed a low process efficiency, in comparison with a two-stage anaerobic system.

The objective of this study was to evaluate the anaerobic treatment of the swine and bovine slaughterhouse effluents in a two-phase anaerobic treatment system, physically separated and serially operated. 


\section{MATERIALS AND METHODS}

Substrate - During the startup process, that had the duration of 20 days, the four reactors were supplied with the effluent from the third stabilization anaerobic pond of a slaughterhouse in the city of Ponta Grossa-PR. Once COD removal reached a steady state, the reactors were supplied with raw swine and bovine slaughter effluent from the same abattoir. The effluent was collected after the flotation and decanter tanks. The effluent was collected in 5-liter polypropylene containers and stored at $-18^{\circ} \mathrm{C}$. During the entire experiment, 30 different lots of the residue were used. The mean characterization of these is presented in Table 1. To feed the reactors, the substrate was acidified with $1 \mathrm{~N}$ sulfuric acid, bringing the $\mathrm{pH}$ near 5.0. The effluent produced by these reactors was used as substrate for the anaerobic filters.

Table 1- Mean characterization of the 30 lots used as substrate (S) and of effluent from the third stabilization pond (E).

\begin{tabular}{lcc}
\hline Parameters & \multicolumn{2}{c}{ Concentration } \\
\cline { 2 - 3 } & $\mathbf{S}$ & $\mathbf{E}$ \\
\hline $\mathrm{pH}$ & $6.2-8.4$ & 8.2 \\
Alkalinity & $283.3-1433.3$ & 850.0 \\
$\left(\mathrm{mgCaCO}_{3} \mathrm{~L}^{-1}\right)$ & & \\
Acidity & $114.0-752.0$ & 60.0 \\
$\left(\mathrm{mgCH}_{3} \mathrm{COOH} \mathrm{L}^{-1}\right)$ & $1200.0-4388.9$ & 641.0 \\
$\mathrm{COD}\left(\mathrm{mgO}_{2} \mathrm{~L}^{-1}\right)$ & $60.3-460.0$ & n.a. \\
Nitrogen $\left(\mathrm{mg} \mathrm{L}^{-1}\right)$ & $9.0-69.0$ & n.a. \\
Phosphorus $\left(\mathrm{mg} \mathrm{L}^{-1}\right)$ & $0.12-0.39$ & 0.13 \\
Total Solids $(\%)$ & $0.04-0.15$ & 0.07 \\
Volatile Solids $(\%)$ & &
\end{tabular}

\section{Reactors}

The experiment was carried out in two sets of the anaerobic reactors constructed of PVC (polyvinyl chloride). Set A, operated at room temperature, consisted of an acidogenic reactor with recirculation (AA) with a working volume of 1.6 L. The recirculation was programmed for 15 minutes at every four hours, with the aid of a fourwatt pump connected to a timer. The pump, SarloS90, had a fixed flow rate of $70 \mathrm{~L} \mathrm{~h}^{-1}$ and recirculated the effluent from the bottom to the top of the reactor (Fig. 1). The methanogenic reactor (MA) was a $1.1 \mathrm{~L}$ upflow biological-filter-type. Polypropylene rings of $1.0 \mathrm{~cm}$ in diameter and 0.5 $\mathrm{cm}$ in length were used as support media on which the biomass could grow. Set B, maintained in a constant room temperature at $32^{\circ} \mathrm{C}$, consisted of an acidogenic reactor without recirculation $(\mathrm{AB})$ with a working volume of $1.4 \mathrm{~L}$. The methanogenic reactor $(\mathrm{MB})$ was a $1.2 \mathrm{~L}$ upflow biological-filter-type. The model for the reactors operated at the room temperature can be seen in Figure 1. The model for the reactors operated at 32 $\pm 1^{\circ} \mathrm{C}$ was the same, but these were immersed in a thermostatically-controlled water bath and did not have the re-circulation pump in the acidogenic phase. The temperature control was made only in the water bath and not inside the reactor. The reactors were serially operated, but the flow was not continuous from the acidogenic to the methanogenic reactor.

\section{Reactor operation}

After the first twenty days of operation, startup period, the HRT for the methanogenic reactors was changed from 20 to 30 days and they started to be supplied with the effluent from the acidogenic reactors, which continued with a 20day HRT and started to be supplied with the raw slaughterhouse effluent. During the experiment, different HRTs were used with the acidogenic and methanogenic reactors. HRTs of 20,5, 2, and 1 day were used in the acidogenic reactors, and HRTs of $30,20,15,10,8,6,4,2$, and 1 day were adopted for the methanogenic reactors. HRT changes were performed every time the organic load removal became stabilized, i.e., when the reactors were in a steady state regime. The 
substrate for the methanogenic reactors under 30day HRT was the effluent from the acidogenic reactors under a 20-day HRT and the substrate for the methanogenic reactors for others HRTs is described in Table 2.

The substrate was added once in a day, independently, in each reactor. The feed volume per day was calculated in function of HRT defined for each reactor and it was increased when steadystate conditions were reached. The reactors inoculum was the effluent from the third stabilization anaerobic pond treating slaughterhouse wastewater.

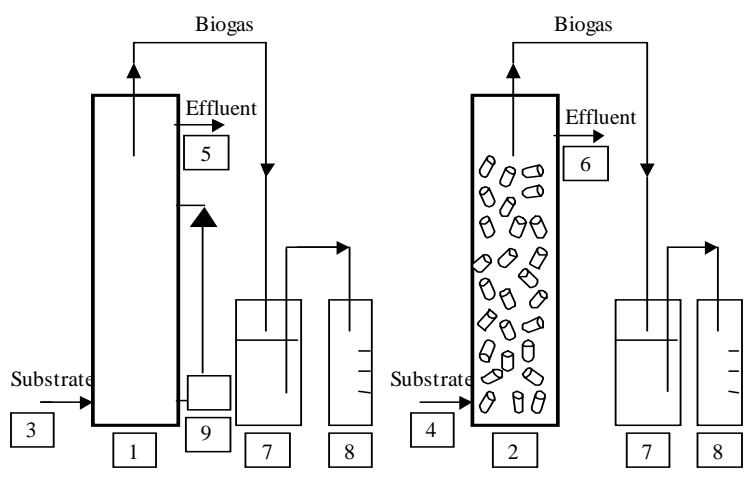

1- Acidogenic reactor (AA)

2- Methanogenic reactor (MA)

3- Acidogenic reactor substrate

4- Methanogenic reactor substrate

5- Acidogenic reactor effluent

6- Methanogenic reactor effluent

7- Flasks filled with acidified saline solution

8- Flasks for collection of the acidified saline solution displaced during the formation of biogas

9- Recirculation pump (Acidogenic reactor set A)

Figure 1- Schematics for set A of acidogênico (AA) and methanogenic (MA) reactors and corresponding gasometer, operated at room temperature

Table 2 - Substrate for methanogenic reactors according to HRTs used in methanogenic and acidogenic reactors.

\begin{tabular}{lc}
\hline Acidogenic reactors HRT (days) & Methanogenic reactors HRT (days) \\
\hline 20 & 30 \\
05 & 20 \\
02 & 20 \\
01 & 15 \\
01 & 10 \\
01 & 08 \\
01 & 06 \\
01 & 04 \\
01 & 02 \\
\hline
\end{tabular}

\section{Gasometer}

In order to measure the volume of biogas produced, four gasometers were prepared in glass flasks filled with acidified saline solution (25\% $\mathrm{NaCl}$ and $\left.3 \% \mathrm{H}_{2} \mathrm{SO}_{4}\right)$. Each flask was closed with a cork containing two exit holes, where two tubes were introduced, one allowing the passage of biogas and the other allowing the passage of acidified saline solution. With the production of gas, the solution was displaced from the flask and 
collected in a graduated plastic cylinder where its volume was measured.

\section{RESULTS AND DISCUSSION}

Tables 3 and 4 present the $\mathrm{pH}$ values for the effluent from the acidogenic and methanogenic reactors as a function of HRT applied and mean room temperatures obtained in set $\mathrm{A}$. The $\mathrm{pH}$ of the substrate in the acidogenic phase was adjusted to 5.0, which increased in the reactors, indicating that the acidogenic and methanogenic phases were not completely separated. The increase in $\mathrm{pH}$ occurs due to the presence of methanogenic archaea that convert the organic acids produced by the acidogenic bacteria into byproducts. As HRT decreased, the development of methanogenic archaea was impaired; the archaea then started to convert acids into $\mathrm{CH}_{4}$ and $\mathrm{CO}_{2}$ at smaller velocities, resulting in the accumulation of organic acids in the reactor, causing a decrease in $\mathrm{pH}$. During the entire experiment, the AA and MA reactors maintained more acidic $\mathrm{pH}$ values than the $A B$ and $M B$ ones, probably due to the variations in the temperature, which inhibited the development of the methanogenic archaea present in both the reactors. In set B, the temperature was controlled at $32^{\circ} \mathrm{C}$ in the jacket.

The reduction in $\mathrm{pH}$ obtained in the acidogenic reactors at shorter HRTs was expected, since it favored the development of the acidogenic bacteria and impaired methanogenic archaeas, optimizing the separation of phases.

Table 3 - Mean $\mathrm{pH}$ results for the effluent from acidogenic reactors $\mathrm{AA}$ and $\mathrm{AB}$, and mean room temperature values for each HRT studied for set A.

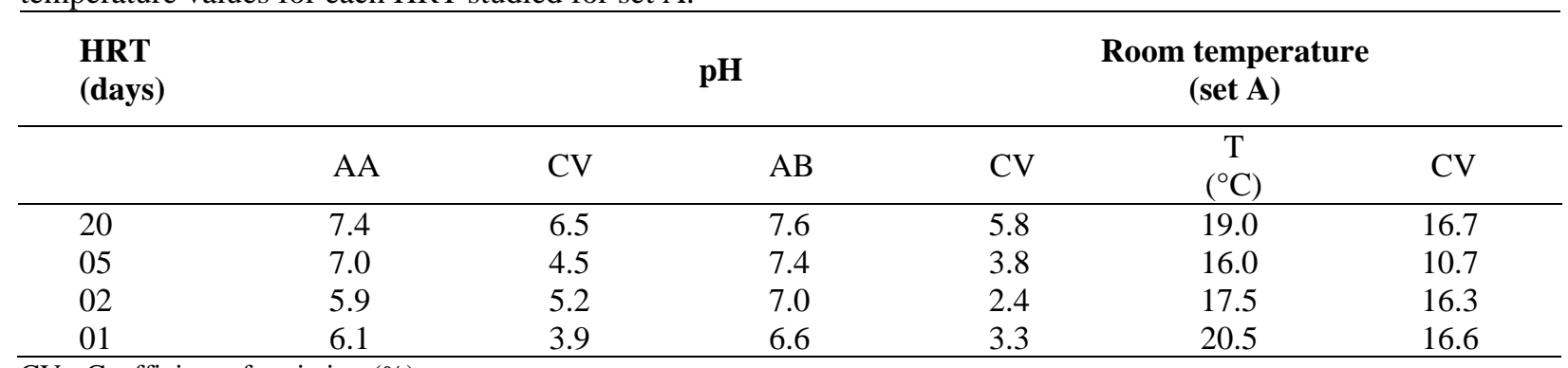

$\mathrm{CV}$ - Coefficient of variation (\%)

$\mathrm{AA}$ - Acidogenic reactor set $\mathrm{A}$ - at room temperature

$\mathrm{AB}$ - Acidogenic reactor set $\mathrm{B}-$ at $32^{\circ} \mathrm{C}$

Table 4 - Mean $\mathrm{pH}$ results for the effluent from methanogenic reactors MA and MB, and mean room temperature values for each HRT studied for set A.

\begin{tabular}{|c|c|c|c|c|c|c|}
\hline \multirow{2}{*}{$\begin{array}{l}\text { HRT } \\
\text { (days) }\end{array}$} & \multicolumn{4}{|c|}{ pH } & \multicolumn{2}{|c|}{$\begin{array}{c}\text { Room temperature } \\
(\text { set A) }\end{array}$} \\
\hline & MA & CV & MB & CV & $\mathbf{T}\left({ }^{\circ} \mathbf{C}\right)$ & CV \\
\hline 30 & 7.0 & 5.1 & 7.5 & 4.9 & 19.0 & 16.7 \\
\hline 20 & 7.3 & 2.7 & 7.5 & 3.4 & 17.0 & 15.6 \\
\hline 15 & 7.1 & 2.4 & 7.3 & 1.9 & 22.0 & 12.6 \\
\hline 10 & 7.1 & 2.4 & 7.3 & 2.3 & 23.0 & 16.1 \\
\hline 08 & 6.9 & 2.5 & 7.0 & 2.4 & 19.0 & 14.9 \\
\hline 06 & 6.8 & 3.2 & 7.0 & 3.2 & 17.0 & 13.9 \\
\hline 04 & 6.8 & 2.1 & 7.1 & 2.0 & 16.0 & 13.6 \\
\hline 02 & 7.0 & 1.4 & 7.1 & 1.9 & 18.0 & 16.2 \\
\hline 01 & 6.8 & 1.4 & 7.1 & 1.4 & 22.0 & 11.5 \\
\hline
\end{tabular}

$\mathrm{CV}$ - Coefficient of variation (\%)

MA - Methanogenic reactor set $\mathrm{A}$ - at room temperature

$\mathrm{MB}-$ Methanogenic reactor set $\mathrm{B}-$ at $32^{\circ} \mathrm{C}$ 
When $\mathrm{pH}$ in the substrate of methanogenic reactors was compared with $\mathrm{pH}$ in their effluent, it showed increase, with the exception of the 30-day HRT, indicating an intake of organic acids by the methanogenic archaeas. It could also be observed that the consumption of acids was higher in the $\mathrm{MB}$, which was again, an indication of the sensitivity of methanogenic archaea to temperature variations. During the entire experiment, the VA/AL ratio (volatile acidity/alkalinity) in the $\mathrm{AB}$ was smaller than 1.0, while AA showed some values higher than 1.0.

Table 5 - Mean volatile acidity (VA) results for the effluent from acidogenic reactors AA and AB, and mean room temperature values for each HRT studied for set A.

\begin{tabular}{|c|c|c|c|c|c|c|}
\hline \multirow[t]{2}{*}{$\begin{array}{l}\text { HRT } \\
\text { (days) }\end{array}$} & \multicolumn{3}{|c|}{$\begin{array}{c}\text { Volatile Acidity } \\
\left(\text { mg CH}_{3} \text { COOH.L }^{-1}\right)\end{array}$} & & \multicolumn{2}{|c|}{$\begin{array}{c}\text { Room } \\
\text { temperature } \\
(\text { set } \mathrm{A})\end{array}$} \\
\hline & $\mathbf{A A}$ & $\mathrm{CV}$ & $\mathbf{A B}$ & $\mathrm{CV}$ & $\mathbf{T}\left({ }^{\circ} \mathbf{C}\right)$ & $\mathrm{CV}$ \\
\hline 20 & n.a. & n.a. & n.a. & n.a. & 19.0 & 16.7 \\
\hline 05 & 567.2 & 21.4 & 353.0 & 3.8 & 16.0 & 66 \\
\hline 02 & 457.2 & 38.3 & 218.2 & 2.4 & 17.5 & 41.1 \\
\hline 01 & 390.7 & 53.4 & 241.7 & 3.3 & 20.5 & 67.9 \\
\hline
\end{tabular}

n.a. - not analyzed

$\mathrm{CV}$ - Coefficient of variation $(\%)$

$\mathrm{AA}$ - Acidogenic reactor set $\mathrm{A}$ - at room temperature

$\mathrm{AB}$ - Acidogenic reactor set $\mathrm{B}-$ at $32^{\circ} \mathrm{C}$

Table 6 - Mean alkalinity (AL) results for the effluent from acidogenic reactors $A A$ and $A B$, and mean room temperature values for each HRT studied for set A.

\begin{tabular}{lcccccc}
\hline \multirow{2}{*}{$\begin{array}{l}\text { HRT } \\
\text { (days) }\end{array}$} & \multicolumn{4}{c}{$\begin{array}{c}\text { Alkalinity } \\
\left(\mathbf{m g ~ C a C O} \mathbf{.} \mathbf{L}^{-\mathbf{1}}\right)\end{array}$} & \multicolumn{3}{c}{$\begin{array}{c}\text { Room temperature } \\
(\mathbf{s e t} \mathbf{A})\end{array}$} \\
\cline { 2 - 8 } & $\mathbf{A A}$ & $\mathbf{C V}$ & $\mathbf{A B}$ & $\mathbf{C V}$ & $\mathbf{T}\left({ }^{\circ} \mathbf{C}\right)$ & $\mathbf{C V}$ \\
\hline 20 & n.a. & n.a. & n.a. & n.a. & 19.0 & 16.7 \\
05 & 977.0 & 25.2 & 1211.0 & 25.7 & 16.0 & 66 \\
02 & 584.0 & 33.0 & 1022.0 & 25.5 & 17.5 & 41.1 \\
01 & 530.1 & 36.7 & 607.0 & 46.3 & 20.5 & 67.9 \\
\hline
\end{tabular}

n.a. - not analized

$\mathrm{CV}$ - Coefficient of variation (\%)

$\mathrm{AA}$ - Acidogenic reactor set $\mathrm{A}-$ at room temperature

$\mathrm{AB}$ - Acidogenic reactor set $\mathrm{B}-$ at $32^{\circ} \mathrm{C}$

In the AA, the highest $\mathrm{VA} / \mathrm{AL}$ values were observed during the period when the inflowing organic load concentration was higher, between 4310.1 and $3089.7 \mathrm{mg} \mathrm{O}_{2} \mathrm{~L}^{-1}$. Based on the $\mathrm{pH}$ and VA/AL results, it became evident that when operated at room temperature, the AA remained more acidified than the $\mathrm{AB}$ operated at controlled temperature. Thus, under the conditions used in this experiment, when it comes to controlling an acidogenic reactor, temperature variations could be advantageous to limit the growth of undesirable microorganisms, such as methanogenic archaea. 
Table 7 - Mean volatile acidity results for the effluent from methanogenic reactors MA and MB, and mean room temperature values for each HRT studied for set A.

\begin{tabular}{|c|c|c|c|c|c|c|}
\hline \multirow{2}{*}{$\begin{array}{l}\text { HRT } \\
\text { (days) }\end{array}$} & \multicolumn{4}{|c|}{$\begin{array}{c}\text { Volatile Acidity } \\
\left(\mathrm{mg} \mathrm{CH}_{3} \mathrm{COOH} . \mathrm{L}^{-1}\right)\end{array}$} & \multicolumn{2}{|c|}{$\begin{array}{c}\text { Room temperature } \\
(\text { set A) }\end{array}$} \\
\hline & MA & $\mathrm{CV}$ & MB & $\mathrm{CV}$ & $\mathrm{T}\left({ }^{\circ} \mathrm{C}\right)$ & $\mathrm{CV}$ \\
\hline 30 & n.a. & n.a. & n.a. & n.a. & 19.0 & 16.7 \\
\hline 20 & 65.3 & 21.3 & 62.9 & 38.9 & 17.0 & 15.6 \\
\hline 15 & 91.6 & 22.3 & 75.0 & 17.6 & 22.0 & 12.6 \\
\hline 10 & 62.4 & 21.8 & 54.8 & 8.8 & 23.0 & 16.1 \\
\hline 08 & 57.2 & 21.3 & 57.2 & 18.8 & 19.0 & 14.9 \\
\hline 06 & 36.6 & 17.8 & 34.6 & 12.5 & 17.0 & 13.9 \\
\hline 04 & 67.6 & 35.1 & 53.6 & 14.1 & 16.0 & 13.6 \\
\hline 02 & 108.2 & 29.2 & 65.2 & 15.6 & 18.0 & 16.2 \\
\hline 01 & 173.5 & 18.4 & 127.9 & 28.9 & 22.0 & 11.5 \\
\hline
\end{tabular}

n.a. - not analized

$\mathrm{CV}$ - Coefficient of variation $(\%)$

MA - Methanogenic reactor set $\mathrm{A}$ - at room temperature

$\mathrm{MB}$ - Methanogenic reactor set $\mathrm{B}-$ at $32^{\circ} \mathrm{C}$

Recirculation into acidogenic reactor set A might also help its higher acidification as the recirculation improved the contact between microorganisms and the substrate. The methanogenic reactors showed VA/AL values between 0.03 and 0.22 .

Figure 2 showed that organic matter removal from the $\mathrm{AB}$ was higher than in the AA. The highest $\mathrm{COD}$ reduction obtained with the $\mathrm{AB}$ was $62.2 \%$, with a substrate COD of $2131.9 \mathrm{mg} \mathrm{O}_{2} \mathrm{~L}^{-1}$ and a two-day HRT, while for the AA the highest reduction in COD was $54.0 \%$, with a substrate
COD of $3083.9 \mathrm{mg} \mathrm{O}_{2} \mathrm{~L}^{-1}$ and a two-day HRT. When HRT changed from two to one day, there was a decrease in COD removal in the AA, which was not observed in the AB. Shorter HRTs favor acidogenesis. The smaller COD removal in the AA could be attributed to the temperature variations. COD removal was high in both the reactors used in the acidogenic phase, $\mathrm{AA}$ and $\mathrm{AB}$. This was an indication of the occurrence of methanogenesis, since the objective in these reactors was the conversion of complex organic matter into fatty acids, which also showed high COD values.

Table 8 - Mean alkalinity (AL) results for the effluent from methanogenic reactors MA and MB, and mean room temperature values for each HRT studied for set A.

\begin{tabular}{|c|c|c|c|c|c|c|}
\hline \multirow{2}{*}{$\begin{array}{l}\text { HRT } \\
\text { (days) }\end{array}$} & \multicolumn{4}{|c|}{$\begin{array}{c}\text { Alkalinity } \\
\left(\mathrm{mg} \mathrm{CaCO}_{3} \cdot \mathrm{L}^{-1}\right)\end{array}$} & \multicolumn{2}{|c|}{$\begin{array}{c}\text { Room temperature } \\
\text { (set A) }\end{array}$} \\
\hline & MA & $\mathrm{CV}$ & MB & $\mathrm{CV}$ & $\mathbf{T}\left({ }^{\circ} \mathbf{C}\right)$ & $\mathrm{CV}$ \\
\hline 30 & n.a.* & n.a.* & n.a.* & n.a.* & 19.0 & 16.7 \\
\hline 20 & 1224.0 & 24.6 & 1291.9 & 27.2 & 17.0 & 15.6 \\
\hline 15 & 1405.0 & 19.7 & 1428.1 & 19.0 & 22.0 & 12.6 \\
\hline 10 & 1019.0 & 19.0 & 1015.6 & 19.1 & 23.0 & 16.1 \\
\hline 08 & 723.0 & 10.8 & 740.4 & 10.7 & 19.0 & 14.9 \\
\hline 06 & 604.0 & 17.9 & 643.0 & 11.0 & 17.0 & 13.9 \\
\hline 04 & 965.0 & 17.8 & 976.2 & 15.8 & 16.0 & 13.6 \\
\hline 02 & 858.0 & 13.9 & 895.2 & 13.6 & 18.0 & 16.2 \\
\hline 01 & 769.3 & 11.1 & 766.6 & 14.4 & 22.0 & 11.5 \\
\hline
\end{tabular}

n.a. - not analized

$\mathrm{CV}-$ Coefficient of variation $(\%)$

MA - Methanogenic reactor set A - at room temperature

$\mathrm{MB}$ - Methanogenic reactor set $\mathrm{B}-$ at $32^{\circ} \mathrm{C}$ 
The methanogenic reactors showed a very similar behavior with regard to COD removal, with very high values. Fig. 3 showed that at HRTs from 20 to two days, COD removal remained practically above $60 \%$, reaching a value of $80 \%$. However, when a one-day HRT was used, there was a decrease in COD removal, reaching $53.5 \%$ and $50.9 \%$ for MB and MA, respectively. Thus, the biological filter operated at room temperature (MA) was as effective as the filter operated at controlled temperature (MB), with regard to COD removal. COD removal in the methanogenic reactors was more related to HRT than to temperature variations (Fig. 3).

The total COD removal efficiency in sets A and B was analyzed for HRTs of five, three and two days. These HRTs corresponded to the HRT sum for each reactor, with an HRT of one day for the acidogenic reactors, and four, two and one day for the methanogenic reactors. Set A, operated at the room temperature, showed COD removal values slightly lower than those in set B; however, both showed good performance in relation to COD removal (Table 9). Wang and Banks (2003) evaluated a two-stage anaerobic digester for the treatment of mixed abattoir wastes and concluded that the two-stage system COD removal was as much as 95\%, more than twice the best performance exhibited by the single-phase system at its loading rate of three $\mathrm{kg} \mathrm{TS} \mathrm{m}^{-3}$ per day.

Table 9- Total COD removal in sets A and B.

\begin{tabular}{lcccccc}
\hline \multirow{2}{*}{ HRT } & \multirow{2}{*}{ COD } & CV & \multicolumn{5}{c}{ Sets A and B } \\
\cline { 4 - 7 } & & & $\mathbf{A}$ & $\mathbf{C V}$ & $\mathbf{B}$ & $\mathbf{C V}$ \\
\hline 05 & 2348.3 & 39.9 & 86.7 & 4.1 & 92.1 & 1.6 \\
03 & 2568.5 & 27.5 & 75.5 & 5.8 & 84.2 & 4.4 \\
02 & 2319.7 & 33.6 & 64.0 & 9.7 & 73.7 & 3.1 \\
\hline
\end{tabular}

COD - $\mathrm{mg} \mathrm{O}_{2} \mathrm{~L}^{-1}$

$\mathrm{CV}$ - Coefficient of variation (\%)

Set $\mathrm{A}$ - operated at room temperature

Set $\mathrm{B}-$ operated at $32^{\circ} \mathrm{C}$

Chávez et al. (2005) used an UASB reactor to treat the poultry slaughter wastewater and obtained removal efficiencies of $40 \%$ with organic volumetric loading of $86.6 \mathrm{~kg}^{\mathrm{BOD} \mathrm{m}} \mathrm{m}^{-3}$ $\mathrm{d}^{-1}$ at $24.0^{\circ} \mathrm{C}$ and $1.5 \mathrm{HRT}$, and of $95 \%$ with organic volumetric loading of $28.7 \mathrm{~kg}$ BOD m$^{-3}$ $\mathrm{d}^{-1}$ at $23.0^{\circ} \mathrm{C}$ and $4.5 \mathrm{HRT}$.

Figs. 4 and 5 showed that methanogenic reactors were similar with regard to biogas production. The volume of biogas produced increased as organic load increased. The variations in temperature did not seem to have affected MA performance. Tables 10 and 11 present the total and volatile solids removals for the acidogenic and methanogenic reactors, respectively. An increase in these parameters was observed during some periods of the experiment, probably due to the loss of biomass, especially in the acidogenic reactors, during the one-day HRT.

Table 12 showed that the nitrogen and phosphorus contents in the effluent from the reactors showed significant variation. For the biological removal of the nutrients ( $\mathrm{N}$ and $\mathrm{P}$ ), an adequate combination of anaerobic, anoxic and aerobic process is necessary (Del Pozo, Diez, 2005). However, both sets of the reactors presented nitrogen removal. This reduction could be explained by the loss in the form of gaseous nitrogen and its conversion into biomass. Polprasert et al. (1992) studied the anaerobic treatment of the slaughterhouse effluent and observed a concentration of nitrogen in the biogas between 20 and $27 \%$, and justified its presence by the input in solubilized form in the reactor substrate, which occured when well-diluted effluents were used. Del Pozo and Diez (2005) worked with an integrated anaerobic-aerobic fixed-film reactor for the slaughterhouse wastewater treatment and achieved a global nitrogen removal efficiency of $67 \%$ for nitrogen loads around $0.084 \mathrm{kgNm}^{-3} \mathrm{~d}^{-1}$. Variations in the phosphorus content could be explained by sampling in places where the collected effluent was not homogeneous, 
containing a higher or lower concentration of biomass, resulting in the variations found. Caixeta et al. (2002) observed increases of 27 and $61 \%$ in the phosphorus contents by treating the slaughterhouse residue in a UASB-type anaerobic reactor.

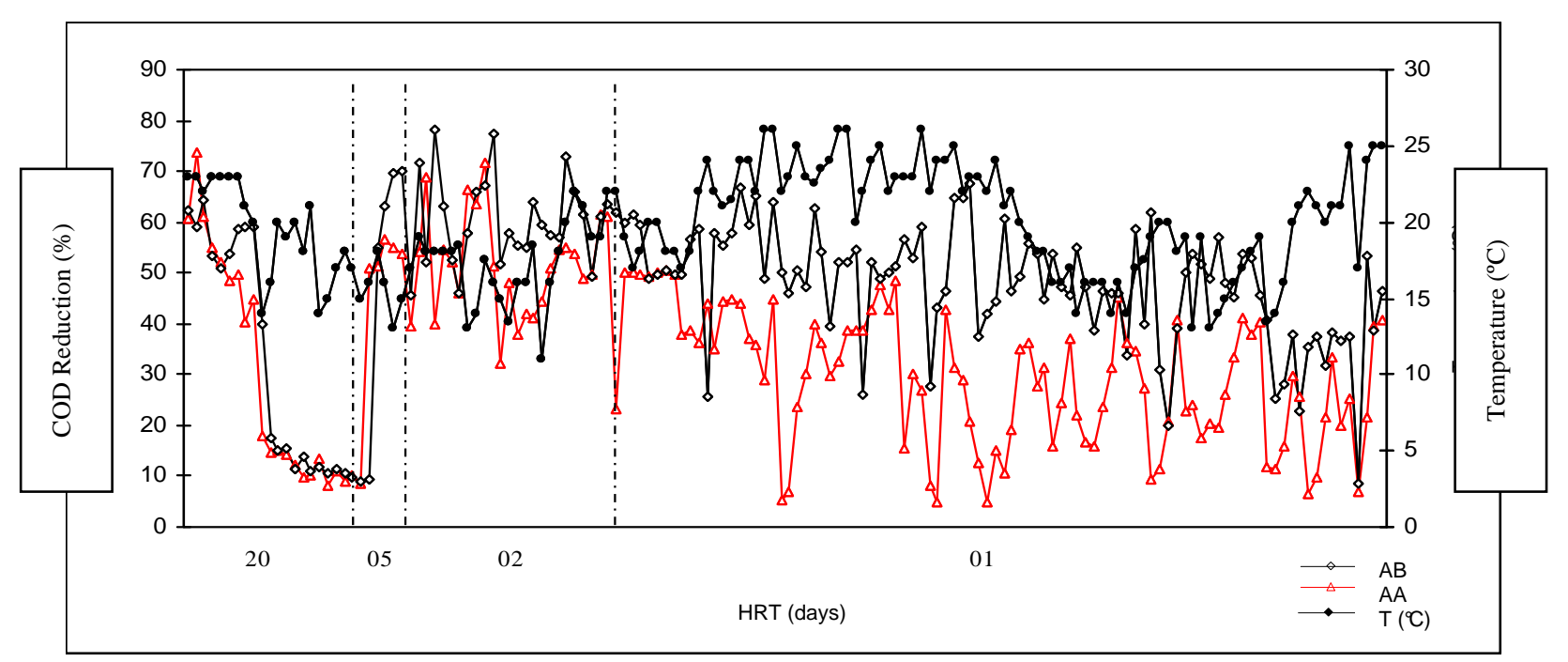

Figure 2 - COD removal from acidogenic reactors at room temperature $(\mathrm{AA})$ and at $32^{\circ} \mathrm{C}(\mathrm{AB})$ as a function of HRTs applied, and the room temperature obtained in set A

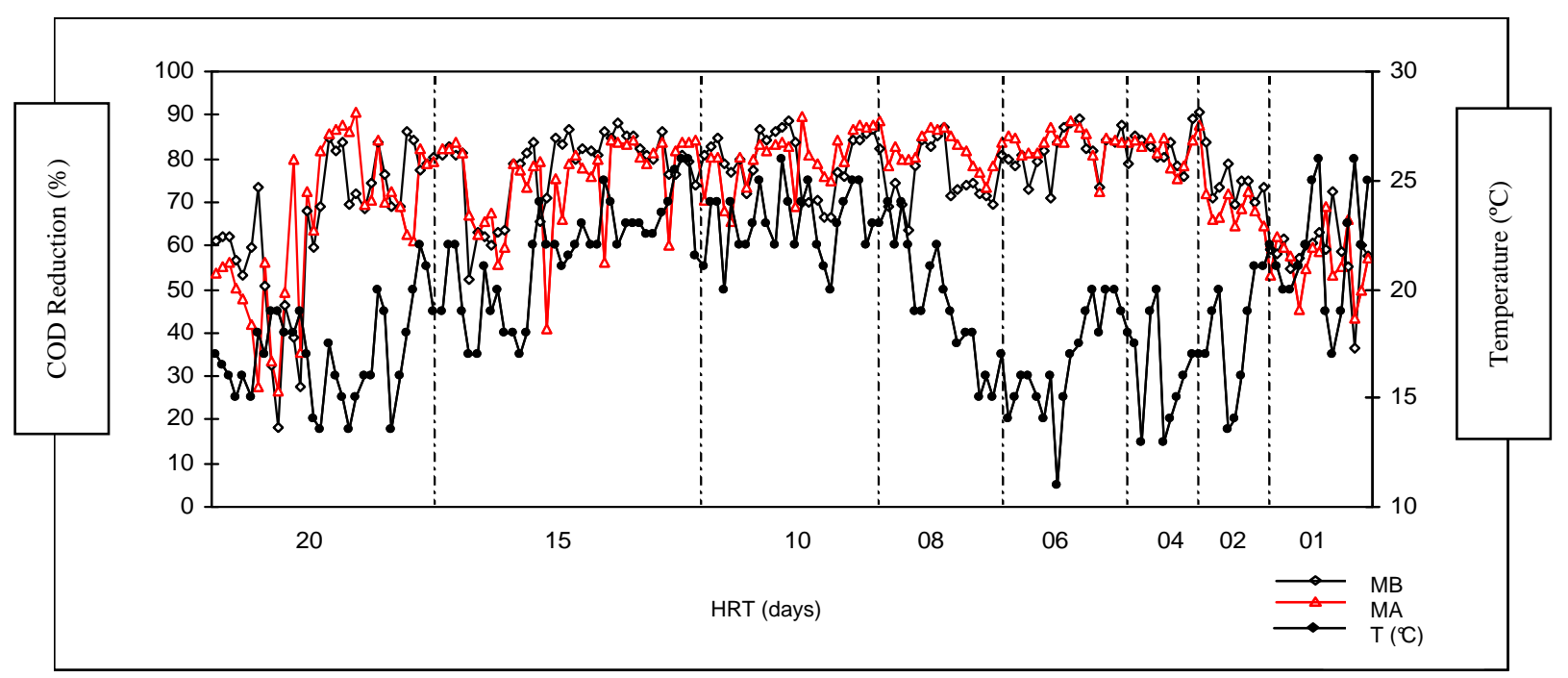

Figure 3 - COD removal from methanogenic reactors at room temperature (MA) and at $32^{\circ} \mathrm{C}$ (MB) as a function of HRTs applied, and the room temperature obtained in set A 


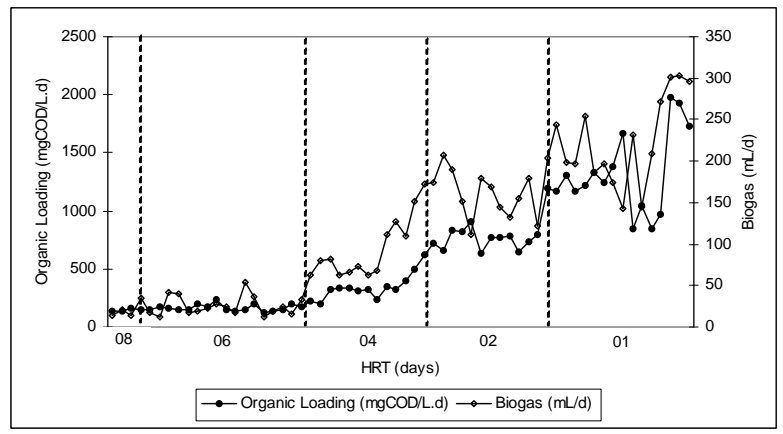

Figure 4 - Biogas volume produced in the methanogenic reactor operated at $32 \pm 1^{\circ} \mathrm{C}(\mathrm{MB})$

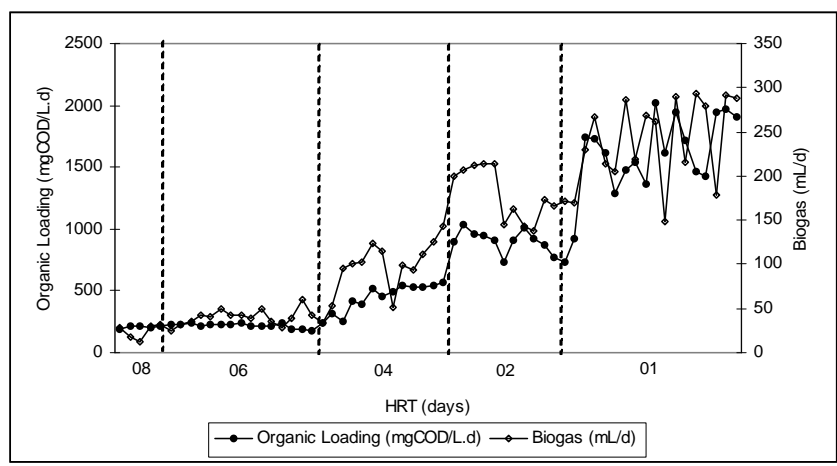

Figure 5 - Biogas volume produced in the methanogenic reactor operated at room temperature (MA)

Table 10 - Reduction in Total and Volatile Solids contents of the effluent from acidogenic reactors at different HRTs.

\begin{tabular}{|c|c|c|c|c|}
\hline \multirow[t]{3}{*}{$\begin{array}{c}\text { HRT } \\
\text { (days) }\end{array}$} & \multicolumn{4}{|c|}{ Reduction (\%) } \\
\hline & \multicolumn{2}{|c|}{ Total Solids } & \multicolumn{2}{|c|}{ Volatile Solids } \\
\hline & AB & $\mathbf{A A}$ & $\mathbf{A B}$ & $\mathbf{A A}$ \\
\hline 2 & 29.0 & 3.8 & -17.3 & -27.4 \\
\hline 1 & 21.1 & 15.1 & 8.9 & 10.9 \\
\hline
\end{tabular}

$\mathrm{AA}-$ Acidogenic reactor set $\mathrm{A}$ - operated at room temperature.

$\mathrm{AB}-$ Acidogenic reactor set $\mathrm{B}-$ operated at $32^{\circ} \mathrm{C}$.

Table 11 - Reduction in Total and Volatile Solids contents of the effluent from methanogenic reactors at different HRTs.

\begin{tabular}{ccccc}
\hline $\begin{array}{c}\text { HRT } \\
\text { (days) }\end{array}$ & \multicolumn{2}{c}{ Reduction (\%) } & \\
\hline & MB & Total Solids & MB & Volatile Solids \\
\hline & 37.1 & MA & 22.4 & 26.5 \\
15 & 30.6 & 35.9 & 8.5 & 10.6 \\
10 & 32.4 & 30.5 & 21.1 & 15.7 \\
8 & 41.4 & 40.7 & 35.4 & 26.4 \\
6 & 38.8 & 39.5 & 18.6 & 26.6 \\
4 & 34.3 & 37.3 & 9.9 & 7.6 \\
2 & 27.6 & 29.2 & 10.8 & 13.5 \\
\hline
\end{tabular}

MA - Methanogenic reactor set A - operated at room temperature

$\mathrm{MB}$ - Methanogenic reactor set $\mathrm{B}-$ operated at $32^{\circ} \mathrm{C}$ 
Table 12 - Variation ranges for nitrogen and phosphorus contents in two sets of reactors.

\begin{tabular}{|c|c|c|}
\hline Nutrients (mg.L ${ }^{-1}$ ) & Set $\mathrm{A}$ & Set $B$ \\
\hline Nitrogen (Substrate) & $89.9-322.7$ & $89.9-322.7$ \\
\hline Nitrogen (Effluent) & $10.5-105.1$ & $14.7-119.5$ \\
\hline Phosphorous (Substrate) & $13.0-68.9$ & $13.0-68.9$ \\
\hline Phosphorous (Effluent) & $9.2-38.3$ & $10.8-32.9$ \\
\hline
\end{tabular}

Set A - operated at room temperature

Set B - operated at $32^{\circ} \mathrm{C}$

\section{CONCLUSION}

From results, it could be concluded that both sets of the reactors showed high COD removal. At the shortest HRT used (one day), the maximum removal obtained was $73.9 \%$ with an organic load of $1973.5 \mathrm{mgO}_{2} \mathrm{~L}^{-1} \mathrm{~d}^{-1}$ for set $\mathrm{A}$, operated at room temperature, and $76.5 \%$ with an organic load of $1726.15 \mathrm{mgO}_{2} \mathrm{~L}^{-1} \mathrm{~d}^{-1}$ for set $\mathrm{B}$, operated at $32^{\circ} \mathrm{C}$, indicating a slight improvement in $\mathrm{COD}$ reduction for the reactors at the controlled temperature of $32^{\circ} \mathrm{C}$. The results indicated that the reactors could be operated at room temperature, thus reducing energy expenses, and an acidogenic phase with recirculation was not necessary either.

\section{RESUMO}

Avaliou-se a eficiência do tratamento anaeróbio de efluente de matadouro de suínos e bovinos em dois conjuntos de biodigestores anaeróbios de duas fases, operados com e sem controle de temperatura. $\mathrm{O}$ conjunto $\mathrm{A}$, formado por um reator acidogênico com recirculação e um filtro biológico de fluxo ascendente, foi operado a temperatura ambiente e o conjunto $\mathrm{B}$, formado por um reator de fluxo ascendente e um filtro biológico de fluxo ascendente, foi mantido a $32^{\circ} \mathrm{C}$. Os reatores metanogênicos apresentaram remoção de DQO acima de $60 \%$ para os TRHs de 20,15, 10, oito, seis, quatro e dois dias. Quando o TRH destes reatores foi mudado para um dia observou-se uma queda da porcentagem de remoção de DQO para $50 \%$. As variações de temperatura parecem não ter prejudicado o desempenho dos reatores do conjunto A.

\section{REFERENCES}

Allie, Z., Jacobs, E.P., Maartens, A., Swart, P. (2003), Enzymatic cleaning of ultrafiltration membranes fouled by abattoir effluent. Journal of membrane science, 218, 107-116.

Anderson, K. G.; Kasapgil, B.; Ince, O. (1994), Microbiological study of two-stage anaerobic digestion during start-up. Water Research., 28, 23832392.

Barreto, C. O. (2004), Tratamento de efluentes na indústria frigorífica - Parte 3. Revista da Carne, 327, 138-141.

Caixeta, C.E.T, Camarota, M.C., Xavier, A.M.F. (2002), Slaughterhouse wastewater treatment: evaluation of a new three-phase separation system in a UASB reactor. Bioresource Technology, 81, 61-69.

Cansian, R.L., Floriani, S.T.R, Valduga, E. (2005), Microbiological analysis of critical points in the chicken industry. Brazilian Archives of Biology and Technology, 48, n.03, 403-406.

Chaves P., C., Castillo L., R., Dendooven, L., Escamilla-Silva, E.M. (2005), Poultry slaughter wastewater treatment with an up-flow anaerobic sludge blanket (UASB) reactor. Bioresource Technology, 96, 1730-1736.

Chen, T. H.; Shyu, W. H. (1998), Chemical characterization of anaerobic digestion treatment of poultry mortalities. Bioresource Technology, 63, 3748.

Chernicharo, C. A. de L. (1997), Princípios do tratamento biológico de águas residuárias: reatores anaeróbios. Belo Horizonte: Segrac.

Del Pozo, R., Diez, V. (2005), Integrated anaerobicaerobic fixed-film reactor for slaughterhouse wastewater treatment. Water Research, 39, 11141122.

Del Pozo, R..; Diez, V.; Beltrán, S. (2000), Pretreatment of Anaerobic of slaughterhouse wastewater that uses fixed-film reactors. Bioresource Technology, 71, 143-149.

Demirer, G.N, Chen, S. (2005), Two-phase anaerobic digestion of unscreened dairy manure. Process Biochemistry, 40, 3542-3549. 
Di Berardino, S.; Costa, S.; Converti, A. (2000), Semicontinuous anaerobic digestion of a food industry wastewater in an anaerobic filter. Bioresource Technology, 71, 261-266.

Halalsheh, M., Sawajneh, Z., Zu'bi, M., Zeeman, G., Lier, J., Fayyad, M., Lettinga, G. (2005), Treatment of strong domestic sewage in a $96 \mathrm{~m}^{3}$ UASB reactor operated at ambient temperatures: two-stage versus single-stage reactors. Bioresource Technology, 96, 577-585.

Ince, O. (1998), Performance of a two-phase anaerobic digestion system when treating dairy wastewater. Water Research, 32, 2707-2713.

Johns, M. R. (1995), Developments in wastewater treatment in the meat processing industry: a review. Bioresource Technology, 54, 203-216.

Kobya, M., Senturk, E., Bayramoglu, M. (2005), Treatment of poultry slaughterhouse wastewater by eletrocoagulation. Journal of Hazardous Materials. In press.

Lima, C.A.A., Ribeiro, R., Foresti, E., Zaiat, M. (2005), Morphological study of biomass during the start-up period of a fixed bed anaerobic reactor treating domestic sewage. Brazilian Archives of Biology and Technology, 48, 841-849.

Massé, D. I.; Masse, L. (2001), The effect of temperature on slaughterhouse wastewater treatment in anaerobic sequencing batch reactors. Bioresource Technology, 76, 91-98.

Mittal, G.S. (2005), Treatment of wastewater from abattoirs before land application - a review. Bioresource Technology. In press.
Núñez, L. A.; Martinez, B. (1999), Anaerobic treatment of slaughterhouse wastewater in na expanded granular sludge BED (EGSB) reactor. Water Science and Technology, 40, 99-106.

Pohland, F.G., Ghosh, S. ( 1971), Developments in anaerobic process. Biotechnology and Bioengineering Symosium., 2, 85-106.

Pohlmann, M. (2004), Tratamento de efluentes na indústria frigorífica - Parte 1. Revista da Carne, 325, $94-98$.

Polprasert,C.;Kemmadamrong, P.; Tran, F. (1992), Anaerobic baffle reactor (ABR) process for treating a slaughterhouse wastewater. Environmental Technology, 13, 857-865.

Ruiz, I.; Veiga, M. C.; Santiago, P. De.; Blázquez, R. (1997), Treatment of slaughterhouse wastewater in a UASB reactor and reactor an anaerobic filter. Bioresource Technology, 60, 251-258.

Torkian, A., Eqbali, A., Hashemian, S.J. (2003), The effect of organic loading rate on the performance of UASB reactor treating slaughterhouse effluent. Resources, Conservation and Recycling, 40, 1-11.

Wang, L., Zhou, Q., Li, F.T. (2006), Biomass and bioenergy, 30, 177-182.

Wang, Z.; Banks, C.J. (2003), Evaluation of a two phase anaerobic digester for treatment of mixed abattoir wastes. Process Biochemistry, 38, 12671273.

Yenigün, O.; Yilmazer, G. (1999), Two phase anaerobic treatment of cheese whey. Water Science and Technology, 40, 289-295.

Received: October 19, 2005;

Revised: May 08, 2006;

Accepted: April 30, 2007. 